\title{
PEMANFAATAN ZAT EKSTRAKTIF LIMBAH SERBUK KAYU ULIN SEBAGAI COATING MEUBEL
}

\author{
Fauziati *)
}

ABSTRACT

\begin{abstract}
This research is aimed to use extracted substances from sawdust of ulin for meubel coating. Extraction and fractionation used the solvent of methanol, $n$ hexan, diethyl ether, ethyl acetat and hot water with the concentration of $1 \%, 2$ $\%, 4 \%$ and $0 \%$ respectively. The meubel is made of rubber wood. By application of the meubel will increase. The highest yield of fractination was achieved by $51,05 \%$ of ethyl acetate and it will inhibit the growth of fungi about $89,09 \%$. The result of phytochemical test showed that the solvent of diethyl ether and ethyl acetate can isolate the most of bioactive compound like alkanoid, saponin, tripenoid and flavonoid. These bioactive compound gives color appearence and durability to the coating product. The results also showed that the bigger concentration resulted in the bigger retention and penetration of the extract. In case of extraction with hot water and $2 \%$ of concentrate gave maximum retention and penetration of $4 \%$.
\end{abstract} Key words : ulin wood waste, rubber wood, coating meubel, extract
substance

\section{PENDAHULUAN}

i Kalimantan Timur kayu ulin adalah jenis kayu yang cukup dikenal sebagai salah satu Sumber Daya Alam, unik dan berharga. Ulin (Belian, Kayu besi, Onglen) atau dengan nama lain disebut Eusideroxylon Zwageri merupakan familia Lauraceae.

Karena sifat mekanis-teknisnya kayu ulin sering digunakan sebagai bahan bangunan, lantai, bantalan kerta api , tiang listrik, kayu kapal, jembatan, kayu perkakas kayu sirap dan lain-lain.

Sifat-sifat kayu ulin dibagi menurut sifat mekanisteknis dan sifat anatominya. Sifat mekanisteknis kayu ulin antara lain, pengerjaan agak sulit, kembang susut kecil, daya retak tinggi, sangat keras dengan serat lurus atau berputar.Sedangkan sifat anatomis kayu ulin adalah kelas kuat 1 , berat jenis maksimum 1,19 , berat jenis minimum 0,88 ,berat jenis rata-rata 1,04, kelas awet 1 ,warna kayu kuning coklat sampai coklat kehitaman jika kena udara berubah hitam.

Kayu ulin bila terendam air meniggalkan warna merah coklat pada air bekas rendaman. Substansi yang menentukan arah warna zat warna alam, merupakan senyawa organik yang terkandung dalam sumber zat warna alam sering disebut dengan coloring matter. Jenis coloring matter yang terdapat dalam zat warna kayu ulin dikenal sebagai Eusiderin. Jenis coloring matter yang terdapat dalam sumber zat warna alam biasanya termasuk golongan tannin, baik hydrolysable tannins maupun condensed tannins.

Tsoumis (1991) dalam Evalina Herawati tentang Warna Alami Kayu (2005) ,menyatakan bahwa warna kayu disebabkan oleh bahan yang dapat diekstrak (tanin dan sebagainya) yang disebut ekstraktif. Ekstraktif adalah bahan kimia dalam kayu yang dapat dilarutkan dalam pelarut netral seperti air dan pelarut organik seperti eter, alkohol, benzene, aceton dan ethil asetat. Kandungan ekstraktif dalam kayu bervariasi mulai kurang $1 \%$ hingga lebih $10 \%$ dan dapat mencapai $20 \%$ lebih untuk kayu tropis.

Flavonoid, stibelina, tannin, antosianin dan eusiderin merupakan golongan zat warna ekstraktif yang ada dikayu. Kemudian Hillis (1987) dalam Evalina Herawati tentang Warna Alami Kayu (2005) mengatakan bahwa flavonoid merupakan senyawa yang menyebabkan kayu teras berwarna merah, kuning dan coklat atau biru. Polifenol dan tannin pada kayu daun lebar memiliki 
kontribusi yang besar pada warna kayu .

Ada beberapa alasan mengapa kayu karet dapat digunakan sebagai subtitusi kayu hutan alam dan menjadi andalan dalam memenuhi kebutuhan kayu baik untuk pasar dalam maupun luar negeri. Alasan tersebut adalah : 1) Sifat-sifat dasar kayu karet, baik sifat fisik, mekanis, maupun kimia relatif sama dengan kayu hutan alam, 2) potensi ketersediaan karet cukup besar sejalan dengan peremajaan perkebunan karet rakyat dan 3) nilai ekonomis kayu karet cukup baik Salah satu sifat kayu karet yang cukup penting adalah kerapatan atau berat jenis ,kerapatan kayu karet tergolong setengah berat yaitu berkisar antara 0,62-0,65 g/cm3. Kayu karet dapat digunakan sebagai pengganti kayu hutan alam setelah melalui proses pengolahan dan pengawetan. Penggunaan kayu karet untuk bahan baku industri sangat cerah mengingat ketersediannya sangat besar dan akan terus meningkat dimasa depan sejalan dengan luasnya areal tanaman karet yang diremajakan, meskipun angka yang pasti belum diperoleh. Namun memiliki kelemahan antara lain nilai penyusutan kayu karet sangat kecil (stabilitas demensi tinggi) hanya sedikit lebih kecil dari pada jati ( Budiman, 1987) dalam Island Boerhandy dan Dewi Shinta Agustina dalam Jurnal Litbang Pertanian dan untuk kelas awet kayu karet tergolong kelas awet $\mathrm{V}$ yaitu setara dengan kayu namun kayu karet lebih rentan terhadap serangga penggerek dan jamur biru (Blue Stain ) yang akan meninggalkan noda pada permukaan kayu walaupun tidak sampai merusak kayu secara fisik. Oleh karena itu dilakukan penelitian dengan tujuan memanfaatkn zat ekstraktif limbah serbuk kayu ulin sebagai coating meuble.

\section{BAHAN DAN METODE}

\section{Bahan dan Peralatan}

Bahan yang digunakan dalam penelitian ini adalah limbah kayu ulin berupa serbuk kayu ulin dengan ukuran $\pm 5 \mathrm{~mm}$, methanol ,n-Hexan, Dietil eter, Etil Asetat dan kayu Karet. Sedangkan peralatan yang digunakan adalah Evaporator ,Pengering Vacum, Tabung Ekstraksi ,Neraca Balance, Botol Sampel, Funnel Separator, Oven Vacum, Rotary Vacum Evaporator dan Botol Timbang

\section{Metode}

\section{Penyiapan Serbuk Kayu Ulin}

Sebelum dianalisis, serbuk kayu ulin dimasukkan kedalam kantong plastik dan disimpan di dalam ruang konstan selama \pm 48 jam agar kadar airnya tidak berubah (konstan). Selanjutnya dilakukan pengukuran faktor kelembaban (moisture factor) dengan menggunakan standar TAPPI T264 om-88

\section{Ekstraksi Serbuk kayu ulin dengan Metanol}

Ditimbang $3 \mathrm{~kg}$ serbuk ulin kering udara yang telah diuji kadar airnya $(7,43 \%)$ kemudian dimasukkan kedalam stoples kaca lengkap dengan tutupnya volume 20 liter kemudian direndam dengan larutan metanol sebanyak 10 liter.

Perendaman dilakukan selama $3 \times 24$ jam, dan selama perendaman dilakukan pengadukan sesering mungkin ,kemudian filtrate dipisahkan dari residu, ekstraksi ini dilakukan sebanyak 3 (tiga) kali setiap perendaman diberlakukan dengan waktu yang sama sampai residu pada saat ditambah pelarut methanol tidak berubah warna menjadi coklat. Setiap kali perendaman menghasilkan filtrate kayu ulin rata-rata sebanyak 8 (delapan) liter.

Selanjutnya filtrat hasil ekstrak metanol, dievaporasi dengan alat Rotary Vacum Evaporator pada suhu maksimal $40^{\circ} \mathrm{C}$, dengan kecepatan putaran $30-40 \mathrm{rpm}$ selama $3 \mathrm{jam}$.

Selanjutnya dievaporasi dalam labu yang telah ditimbang terlebih dahulu beratnya dan dievaporasi hingga kering (solid seperti pasta).

Kemudian dikeringkan lanjut dengan oven selama 1 (satu) jam pada suhu $105^{\circ} \mathrm{C}$. Setelah dingin ditimbang, sehingga diketahui berat total ekstrak methanol.

Eter.

Ekstrak metanol ini kemudian di fraksinasi dengan pelarut $n$-Hexan, etil Asetat dan Dietil

Larutan yang telah dikentalkan ini kemudian dimasukkan kedalam funnel separator, kemudian ditambahkan pelarut $\mathrm{n}$-Hexan sebanyak $\pm 75 \mathrm{ml}$ dan sedikit aquades $( \pm 25 \mathrm{ml}$ ). Campuran ini dikocok dan dibiarkan sehingga terjadi pemisahan. Setelah terjadi pemisahan, fraksi terlarut $n$-heksan dipisahkan dari residu. Fraksinasi ini dilakukan sebanyak empat kali. Fraksi terlarut $n$-heksan yang diperoleh dimasukkan kedalam botol tertutup rapat.

Residu $n$-heksan dimasukkan kedalam funnel separator dan kedalamnya ditambahkan pelarut di etil eter sebanyak $\pm 75 \mathrm{ml}$. Campuran dikocok dan dibiarkan sehingga terjadi pemisahan.

Setelah terjadi pemisahan, fraksi terlarut diethil $\in$ ter dipisahkan dari residu. Fraksinasi ini dilakukan 
sebanyak empat kali. Kemudian fraksi terlarut di etil eter yang diperoleh dimasukkan kedalam botol yang tertutup rapat.

Fraksinasi terakhir adalah dengan menggunakan pelarut etil asetat. Residu ekstrak di etil eter yang telah dimasukkan kedalam funnel separator kemudian dicampur dengan pelarut etil asetat sebanyak $\pm 75 \mathrm{ml}$. Campuran ini dikocok dan dibiarkan sehingga terjadi pemisahan , setelah terjadi pemisahan fraksi terlarut etil asetat dipisahkan dari residu. Fraksinasi ini juga dilakukan sebanyak empat kali. Fraksi terlarut etil asetat yang diperoleh dimasukkan kedalam botol yang tertutup rapat.

Ketiga fraksi tersebut ( $n$-hexan, dietil eter dan etil asetat) masing-masing dievaporasi hingga kering, setelah dioven selama tiga jam pada suhu $105^{\circ} \mathrm{C}$, sehingga dari masing-masing fraksi dapat diketahui berat total. Secara skematis urutan fraksinasi ini dapat dilihat pada skema fraksinasi ekstraksi serbuk kayu ulin.( Gambar 1)

Tahap selanjutnya adalah pembuatan larutan ekstrak dengan berbagai konsentrasi $(1 \%, 2$ $\%, 4 \%$ ) dan control $(0 \%)$, dengan menggunakan pelarut aseton. Untuk membuat larutan ekstrak aseton diperhatikan konsentrasi awal yang diketahui. Sedangkan untuk pembuatan larutan ketiga ekstrak yang lain, bisa diperhitungkan dari jumlah masing-masing berat kering hasil fraksinasi yang diperoleh. Dengan demikian diperoleh larutan dengan konsentrasi $4 \% .2 \%$ dan $1 \%$ dan kontrol $(0 \%)$.

\section{Ekstrasi Serbuk Kayu Ulin Dengan Air Panas}

Ditimbang $3 \mathrm{Kg}$ serbuk kayu ulin kering udara yang telah diuji kadar airnya $( \pm 7,43 \%)$ dimasukan kedalam dandang stainless kemudian ditambahkan air hingga perbandingan antara serbuk kayu ulin dan air $2 / 4: 3 / 4$. Kemudian ditutup dan dipanaskan selama 3 jam sambil diaduk setiap air berkurang ditambahkan sampai mencapai perbandingan semula.

Setelah selesai pemasakan kemudian didinginkan dan disaring untuk diambil filtratnya ,kemudian diambil $50 \mathrm{ml}$ dari filtrat tersebut masukan dalam gelas piala yang telah ditimbang berat kosongnya dan dipanaskan di Oven selama 24 jam sampai kering.

Selanjutnya gelas beker dimasukkan dalam Desikator kemudian ditimbang sampai berat konstan untuk mengetahui solid content (konsentrasi larutan tersebut). Untuk membuat larutan dengan konsentrasi $1 \%, 2 \%$ dan $4 \%$.

Analisis Fitokimia Zat Ekstraktif Kayu Ulin meliputi :
a.Pengujian Larutan alkaloid (Harborne, 1987)
b. Pengujian steroid dan triterpenoid (Harborne, 1987)
c. Pengujian saponin (Harborne, 1987)
d. Pengujian flavonoid (Harborne, 1987)
e. Pengujian karbohidrat (Harborne, 1987)

Pengujian Aktivitas Anti Jamur

$$
(\%)=1-\frac{T}{C} \times 100 \%
$$

Dimana:
(\%)
T
$=$ Nilai hambatan pertumbuhan jamur $(\%)$
C
$=$ Pertumbuhan jamur pada sampel dengan perlakuan $(\mathrm{cm} 2)$
$=$ Pertumbuhan jamur tanpa perlakuan $(\mathrm{cm} 2)$

\section{Pembuatan Contoh Uji \\ Persiapan Pembuatan Contoh uji}

Batang kayu karet dibuat dolog dengan panjang \pm 1 meter, kemudian diambil kayu bagian terasnya untuk dibuat kayu contoh uji. Pemilihan bagian dolog yang diambil dilakukan secara acak pada bagian kayu teras

Dolog yang telah dibelah menjadi bentuk papan, dibelah lagi hingga diperoleh kayu dalam bentuk tongkat (stick) dengan lebar $3 \mathrm{~cm}$, dengan menggunakan mesin serut dilakukan perataan permukaan hingga diperoleh contoh uji berukuran panjang $51,80 \mathrm{~mm}$,lebar $25,31 \mathrm{~mm}$ dan tebal $16,51 \mathrm{~mm}$ tanpa cacat. 


\section{Ukuran Dan Jumlah Contoh Uji}

Ukuran contoh uji didasarkan pada "Eurepean Standard Spesification EN 113" (Valoke, 1985), contoh uji sebanyak 48 buah (dengan 3 macam bahan pelarut ekstraktif yaitu, dietil eter, etil asetat dan n-Heksan dan air panas dengan konsentrasi 1\%,2\%,4\% dan kontrol dengan 3 kali ulangan.

Untuk mengetahui ketahan zat ekstraktif kayu ulin terhadap serangan jamur ada 2 (dua) pengamatan yang dilakukan yakni pengamatan terhadap ketahan zat ekstraktif serbuk kayu ulin terhadap jamur dan zat ekstraktif kayu ulin terhadap kayu karet yang telah dikoating zat ekstraktif .

\section{Pengawetan Contoh Uji}

Contoh uji serelah kering udara kedua ujungnya ditutup dengan cat, kemudian dikeringkan dan diukur kadar airnya. Setelah mencapai kering udara, kemudian sebelum dilakukan coating terhadap zat ekstraktif dan resin formaldehid dikeringkan dalam oven pada suhu $105^{\circ} \mathrm{C} \pm 2{ }^{\circ} \mathrm{C}$ selama $2 \times 24$ jam.

Proses pengawetan dilakukan dengan metode perendaman dingin selama 24 jam. Dalam proses pengawetan ini digunakan 12 wadah gelas piala untuk 4 macam ekstrak terdiri dari ekstrak dietil eter, $n$-hexan, etil asetat dan air panas dengan 4 taraf konsentrasi yakni $0 \%$ (control), $1 \%, 2 \%$ dan $4 \%$. Masing-masing wadah terdiri dari 3 contoh uji ( 3 ulangan), sebelum dan sesudah perendaman dilakukan penimbangan terhadap contoh uji, agar diketahui berat larutan zat ekstraktif yang masuk kedalam kayu (Retensi). Selanjutnya contoh uji dikeringkan udara.

\section{Penyediaan Biakan Jamur (Isolasi Jamur)}

Media biakan jamur yang digunakan adalah MEA (Malt Extract Agar), dengan komposisi 15 gram, Bacto Agar $20 \mathrm{gram}$ bahan-bahan tersebut dilarutkan dalam $1000 \mathrm{ml}$ aquades dan dipanaskan hingga mendidih. Setelah media agak dingin, dimasukkan kedalam stoples yang telah dibersihkan, stoples ditutup dengan kapas yang dibungkus dengan kertas tissue dan bagian luarnya ditutup dengan aluminium foil. Agar diperoleh media yang steril, media tersebut dimasukkan kedalam autoclave selama 15 menit pada tekanan 15 psi. Setelah itu media dibiarkan 3-4 hari sampai padat.

Setelah media cukup padat, jamur pelapuk yang diperoleh dari biakan murni diinokulasi. Pembiakan jamur dengan menggunakan spora yang diletakkan diatas media. Pengamatan dilakukan beberapa hari untuk melihat pertumbuhan jamur.

Inkubasi dilakukan selama 2 minggu, dengan temperatur kamar $\pm 27{ }^{\circ} \mathrm{C}$ dan $\mathrm{RH}$ (kelembaban) $\pm 80 \%$. Setelah itu jamur siap untuk diinokulasi pada contoh uji sesuai dengan perlakuan masing-masing, tepat ditengah-tengah media. Stoples ditutup kembali dengan rapat dan penutup bagian luarnya diberi aluminium foil kemudian diinkubasi selama 8 minggu. Sebelum dan sesudah pengumpanan dilakukan penimbangan terhadap contoh uji untuk mengetahui prosentase kehilangan berat (weight loss) contoh uji dengan melihat tingkat serangan jamur pada contoh uji dengan rumus sebagai berikut:

\section{Dimana,}

$$
A=W-F \times 100 \%
$$

$A=$ Prosentase penurunan berat kayu

$\mathrm{W}=$ Berat kering kayu sebelum diumpankanke jamur

$F=$ Berat kering kayu setelah diumpankan ke jamur

Disamping itu dilakukan pula inokulasi terhadap ekstrak zat ekstraktif dari fraksinasi pelarut air panas, $n$-heksan, dietil eter dan etil asetat dengan berbagai konsentrasi $(0 \%, 1 \%, 2 \%$ dan $4 \%)$ untuk diamati penghambatan pertumbuhan jamurnya, dengan menggunakan rumus sebagai
berikut:

\section{Persentase penghambatan $(\%)=(1-(T / C)) \times 100$}

Dimana,

$T=$ luas pertumbuhan jamur dengan perlakuan $(\mathrm{cm} 2)$

$\mathrm{C}=$ luas pertumbuhan jamur tanpa perlakuan (kontrol, $\mathrm{cm} 2$ )

\section{HASIL DAN PEMBAHASAN}

Ekstraksi serbuk kayu ulin dengan menggunakan pelarut methanol menghasilkan randemen sebesar $17,90 \%$.

Sedangkan fraksinasi dari ekstrak methanol dengan menggunakan pelarut $n$ - heksan Fauziati 
menghasilkan randemen sebesar $5,49 \%$, dengan dietil eter menghasilkan randemen sebesar $22,28 \%$, dengan ethil asetat menghasilkan randemen sebesar $51,03 \%$.

Fraksinasi adalah pemisahan komponen ekstraktif dengan menggunakan beberapa pelarut berdasarkan perbedaan polaritasnya. Hasil analisis menunjukkan bahwa fraksinasi dengan menggunakan pelarut Organik seperti etil asetat menghasilkan randemen ekstrak zat ekstraktif paling besar, hal tersebut terjadi karena etil asetat mempunyai nilai polaritas yang paling tinggi yakni sebesar 1,75 Debye, di ether sebesar 1,15 Debye dan $n-H e x a n$ adalah nol Debye. Disamping itu besar partikel ekstrak juga mempengaruhi proses ekstraksi, semakin kecil partikel semakin pendek jalan yang harus ditempuh pada perpindahan massa dengan cara difusi dan perbedaan titik didih antara ekstrak dan pelarut tidak terlalu besar. Disamping itu faktor yang mengakibatkan besarnya randemen adalah sifat dari senyawa bioaktif pada kayu, yaitu mudah diperoleh dengan menggunakan pelarut organik disamping itu banyaknya zat ekstraktif yang dapat larut juga sangat dipengaruhi oleh faktor pemilihan pelarut. Guenther (1987), mengatakan bahwa pelarut yang ideal untuk proses ekstraksi harus memenuhi syarat antara lain : (1) dapat melarutkan zat ekstraktif,(2) mempunyai titik didih yang seragam (3) pelarut harus bersifat inert karena hal iniakan mengakibatkan hilangnyaksi,(4) mempunyai titik didih yang cukup rendah karena hal ini akan mengakibatkan hilangnya sebagian pelarut akibat penguapan.

Pemilihan pelarut, meskipun memegang peranan penting dalam proses ekstraksi, namun bukan satu-satunya faktor yang dapat menentukan tinggi rendahnya hasil ekstraksi. Sesuai dengan pernyataan Harbone (1987), kualitas dan banyaknya ekstraksi pada serbuk kayu ulin karena dipengaruhi oleh kondisi bahan baku yang digunakan terutama untuk analisis fitokimia harus digunakan bahan yang segar. Sedangkan dalam proses ekstraksi, perlu diperhatikan mengenai kemungkinan sampel yang tidak terekstrak sempurna (misalnya residu sampel yang di ekstrak tidak sampai bening )dan lain-lain. Faktor lain yang berperan adalah temperatur, khususnya ekstraksi dengan menggunakan pelarut air dengan proses pemanasan akan

Analisis Fitokimia Terhadap Fraksi-Fraksi Dari Ekstrak Ulin yang cukup tinggi.

Analisis fitokimia adalah untuk mengetahui senyawa bio aktif dalam zat ekstraktif, seperti alkaloid, tripenoid, steroid, saponin, flafonoid dan karbohhidrat dengan proses ekstraksi dan fraksinasi (isolasi) dengan pelarut organik yang sesuai.

Tabel 1. Hasil Analisis Fitokimia Terhadap Fraksi-Fraksi dari Ekstrak Uli

\begin{tabular}{|c|c|c|c|c|c|c|c|}
\hline Pelarut & Metode ekstraksi & Alkoloid & Triterpenoi & Steroid & Saponin & Flavonoid & Karbohidrat \\
\hline Metanol & Dingin & - & - & - & - & - & ++ \\
\hline$n$-Heksan & Fraksinasi & - & - & - & - & - & ++ \\
\hline Di-Etil Eter & Fraksinasi & + & + & - & + & + & ++ \\
\hline Etil Asetat & Fraksinasi & + & + & - & - & + & ++ \\
\hline
\end{tabular}

Hasil analisis fitokimia terhadap zat ekstraktif menunjukkan bahwa ekstraksi dengan pelarut methanol dingin alkaloid negatif, triterpenoid negatf, saponin negatif, flavonoid negative dan karbohidrat positif. Sedangkan fraksinasi n Heksan dari ekstraksi methanol menghasilkan Alkaloid negative,triterpenoid negative, steroid negative, saponin negative, flavonoid negative dan karbohidrat banyak sekali. Fraksinasi DiEthil Ether, Alkaloid positif ,tripernoid positif, steroid negative, Flavonoid positif karbohidrat banyak sekali. Sedangkan Fraksinasi Etil Asetat, alkaloid positif, triterpenoid positif, steroid negative,saponin negative, flavonoid positif dan karbohidrat
banyak sekali.

Dari hasil analisis Fitokimia terhadap Fraksi-fraksi Ekstrak ulin pelarut organic diethil Eter memberikan kemapuan fraksinasi paling besar, yaitu 4 (empat) macam zat ekstraktif sesuai yang terkandung dalam bahan ekstraksinya yakni serbuk kayu ulin dan satu fraksi zat ekstratif yang terkandung di kayu ulin yang masih muda yaitu karboksilat, sedangkan pelarut organik etil asetat memberikan hasil fraksinasi terhadap zat ekstraktif yaitu 3 (tiga) macam zat ekstraktif yang sesuai dengan bahan ekstraksinya serbuk kayu ulin dan satu fraksi zat ekstraktif yang bukan terkandung di kayu ulin (karbohidrat). Pelarut organik diethil eter dan etil asetat dapat mengisolasi senyawa bio aktif paling besar dari pada pelarut organik yang lain hal ini terjadi karena sifat pelarut organik 


\section{Retensi Ekstrak Kayu Ulin Pada Kayu Karet}

Tabel 3. Nilai Retensi Ekstrak Kayu Ulin pada Kayu Karet

\begin{tabular}{|c|c|c|c|c|c|}
\hline \multirow{2}{*}{ Konsentrasi Pelarut } & \multicolumn{5}{|c|}{ Rataan Retensi Ekstrak pada Kayu Karet ( kg/m3) } \\
\cline { 2 - 6 } & Methanol & n-Heksan & Dietil Eter & Etil Asetat & Air Panas \\
\hline $1 \%$ & 1,85 & 2,01 & 1,87 & 2,03 & 1,95 \\
\hline $2 \%$ & 3,36 & 3,59 & 4,09 & 3,83 & 8,1 \\
\hline $4 \%$ & 7,29 & 8,11 & 6,70 & 7,66 & 5,5 \\
\hline
\end{tabular}

Keterangan : rata-rata dari 3 (tiga) ulangan

Retensi zat ekstraktif sebagai bahan pengawet kayu merupakan faktor yang mempengaruhi keefektifan bahan pengawet dalam memperpanjang umur pemakaian kayu yang diawetkan, hasil penelitian menunjukkan bahwa retensi rata-rata bahan pengawet ekstraktif kayu ulin pada konsentrasi $1,85 \mathrm{Kg} / \mathrm{m} 3$ sampai dengan $8,10 \mathrm{Kg} / \mathrm{m} 3$.

Hasil analisis menunjukkan bahwa semakin besar konsentarsi zat ekstraktif ,maka semakin besar pula retensinya (gambar 1). Sedangkan untuk mengetahui hubungan antara konsentrasi dan retensi zat ekstraktif untuk semua pelarut $n$-Hexan, etil eter dan etil Asetat kecuali pada ekstraksi dengan pelarut air panas, dimana pada konsentrasi $2 \%$ memberikan retensi yang maksimum karena pada konsentrasi tersbut partikel partikel larutan tersebut dapat meresap dinding kayu maksimal dibandingkan konsentrasi yang lebih tinggi yakni $4 \%$. (gambar 2 ).

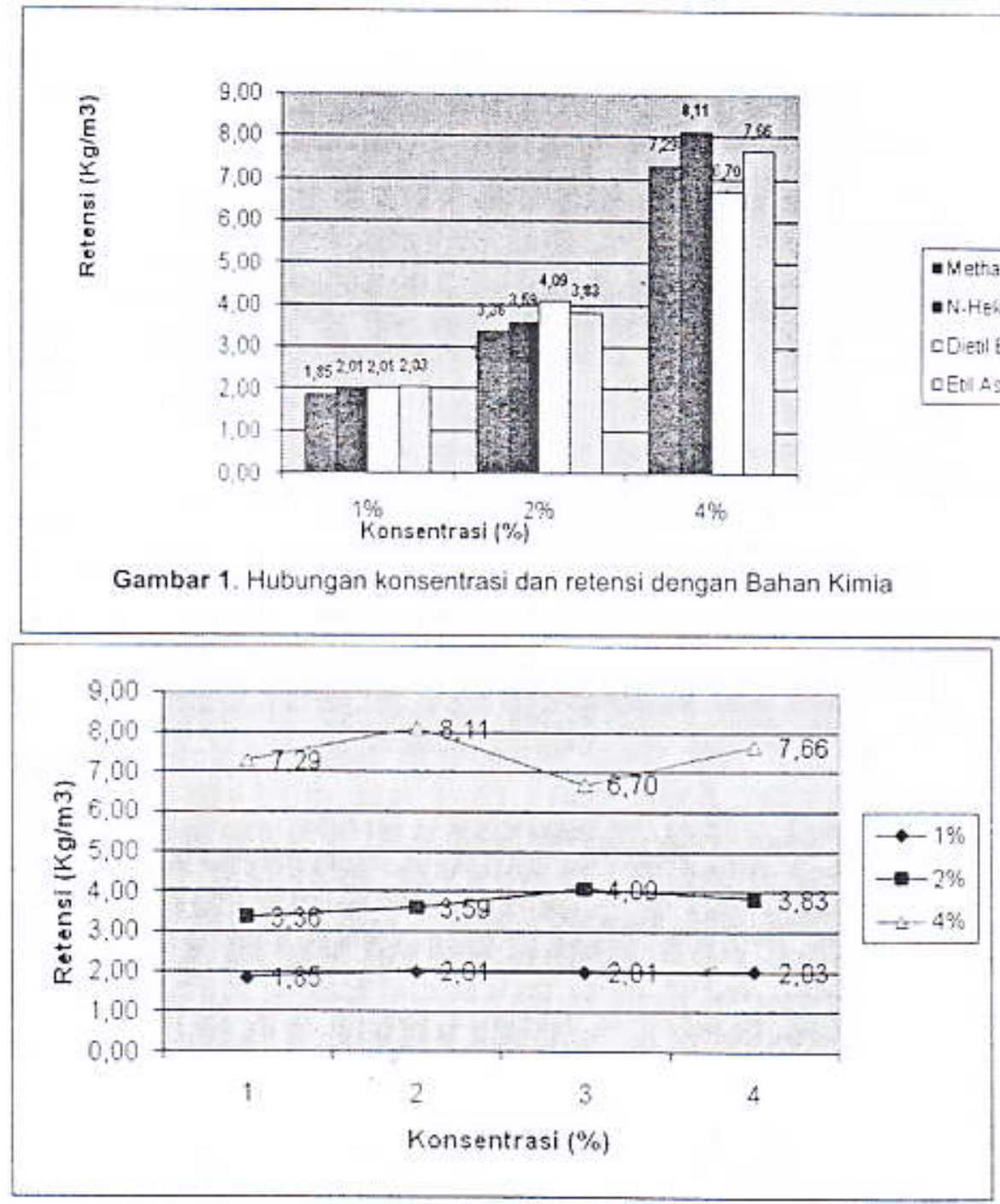

Gambar 2. Hubungan konsentrasi dan retensi dengan Prosentase 
Tabel 4. Nilai Penetrasi Ekstrak Kayu Ulin pada Kayu Karet

\begin{tabular}{|c|c|c|c|c|c|}
\hline \multirow{2}{*}{ Konsentrasi Pelarut } & \multicolumn{5}{|c|}{ Rataan Retensi Ekstrak pada Kayu Karet ( kg/m3) } \\
\cline { 2 - 6 } & Methanol & n-Heksan & Dietil Eter & Etil Asetat & Air Panas \\
\hline $1 \%$ & 8,15 & 7,83 & 8,19 & 8,53 & 10,34 \\
\hline $2 \%$ & 8,19 & 8,48 & 8,46 & 8,55 & 10,72 \\
\hline $4 \%$ & 8,13 & 8,47 & 8,17 & 8,48 & 10,56 \\
\hline
\end{tabular}

Penetrasi adalah masuknya zat ekstraktif kedalam contoh uji menurut arah panjang kayu ( longitudinal), sehingga pengamatan penetrasi hanya dilakukan pada arah panjang kayu Penetrasi rata-rata pada panjang kayu contoh uji adalah 7,83-10,72 mm. Jenis bahan ekstraksi dan proses ekstraksi berpengaruh terhadap penetrasi hal tersebut ditunjukkan oleh penetrasi dengan menggunakan air panas pada konsentarsi $2 \%$ memberikan penetrasi maksimal (paling besar), kemudian etil asetat.

\section{KESIMPULAN DAN SARAN \\ Kesimpulan}

Zat ekstraktif kayu ulin disamping memberkan warna khas kayu ulin coklat merah (Eusiderin ), dan dapat menghambat serangan jamur.Diperoleh rendemen terbesar dalam fraksinasi zat ekstraktif dengan pelarut organik etil asetat sebesar $51,03 \%$ dan menghambat serangan jamur paling besar yaitu $89,09 \%$. Hasil analisa fitokimia menunjukkan bahwa pelarut organik dietil eter dan etil asetat dapat mengisolasi senyawa bio aktif yang paling banyak yakni alkaloid, saponin, triterpenoid dan flavonoid. Makin besar konsentrasi semakin besar pula retensi penetrasi,keawetan kayu,warna kayu. Hasil analisa retensi menunjukkan bahwa semakin besar konsentrasi , maka semakin besar pula retensinya, begitu pula penetrasinya yang akan memberikan keawetan terhadap kayu. Disamping itu memberikan penampakan warna yang kuat, dan khusus untuk ekstrasi serbuk kayu ulin dengan air panas konsentrasi $2 \%$ memberikan penetrasi yang lebih besar dan warna lebih tajam dari pada $4 \%$.

\section{Saran}

Sebaiknya kedepan dicoba ekstraksi serbuk kayu ulin dengan menggunakan air panas, karena mudah pelaksanannya, lebih murah dan peralatan yang digunakan sederhana dan mudah diterapkan di UKM.

\section{DAFTAR PUSTAKA} Budiman ,1987. Peluang Kayu Karet sebagai subtitusi kayu hutan , Jurnal litbang Pertanian
Jakarta.

Evalina E 2005. Warna Alami Kayu http://www encyclopedia .com/warna alami kayu Guenter. E, 1987. MinyakAtsiri Penerbit Universitas Indonesia(UI-Press)

Harbone, J.B. 1987. Metode Fitokimia (terjemahan) Terbitan Ke 2 Penerbit ITB Bandung .

Hadikusuma, 2005 . Isolation and Identification Of Antifungal Compo and Tropical and Temperate Woods. Dissertation. Ehime University .Japan.144pp 